\title{
Bacterial carbon dynamics on marine snow
}

\author{
Meinhard Simon $^{1, *}$, Alice L. Alldredge ${ }^{2}$, Farooq Azam \\ ${ }^{1}$ Scripps Institution of Oceanography A-002, University of California, San Diego, La Jolla, California 92093, USA \\ ${ }^{2}$ Department of Biological Sciences and Marine Science Institute, University of California, Santa Barbara, Santa Barbara,
} California 93106, USA

\begin{abstract}
We studied the biomass and production of heterotrophic bacteria on several types of marine snow including those composed predominantly of diatoms, fecal pellets, larvacean house mucus, or miscellaneous detrital components at 8 stations in the Pacific Ocean off California. We concurrently measured photoautotrophic biomass and production, and particulate organic carbon (POC) on marine snow to examine the quantitative significance of bacterial processes in carbon flow pathways in different types of marine snow. Although a typical marine snow floc contained about $10^{6}$ bacteria, the bacterial carbon (BOC) and phytoplankton carbon (PhytoC) were each $<13 \%$ of total POC. Most of the floc carbon therefore consisted of detritus, unlike whole seawater samples (in other studies) where BOC + PhytoC generally comprises about $50 \%$ of the POC. PhytoC on marine snow and in the surrounding water was generally similar to BOC (except at one station). Floc POC turnover time based on bacterial carbon demand, assuming a $30 \%$ carbon assimilation efficiency, was 20 to $100 \mathrm{~d}$. This was comparable to the POC residence time reported for the Southern California Bight. Bacterial specific growth rates on flocs varied greatly between stations $\left(0.06\right.$ to $\left.0.96 \mathrm{~d}^{-1}\right)$ with highest values at stations with diatom flocs where they were comparable to growth rates of free-living bacteria in mesotrophic waters. The ratio of bacterial carbon production to primary production on marine snow was typical of seawater samples from other studies. Bacterial carbon production was measured by the leucine incorporation method while bacterial cell production (and growth rate) was measured by the thymidine incorporation method simultaneously on the same marine snow floc. We could thus calculate bacterial carbon per-new-cell $\left(C_{n}\right)$ and compare it with the microscopy-based average carbon per cell $\left(C_{a v}\right)$ to test the hypothesis that new cells reflect the average carbon content of the parent assemblage (bacteria on marine snow were much larger than those in the surrounding water). In $73 \%$ of our samples the carbon content of the new daughter cells was within a factor of 1.5 of the carbon content of the parent cells.
\end{abstract}

\section{INTRODUCTION}

Flocculent organic aggregates, greater than $0.5 \mathrm{~mm}$ in diameter, known as marine snow, are a ubiquitous component of marine surface waters. These macroscopic particles are enriched in organic matter and are inhabited by a rich and diverse community of living phytoplankton, protozoans, and bacteria at densities 1 to 2 orders of magnitude higher than populations found freely suspended in the surrounding seawater. The nature of this detrital community and its contribution to biological processes in the marine pelagic zone have been described previously (reviewed by Alldredge \& Silver 1988, Alldredge \& Gotschalk 1990). However, the role of attached bacteria in aggregate degradation

\footnotetext{
- Present address: Limnological Institute, University of Constance, PO Box 5560, D-7750 Konstanz, F.R. Germany
}

and the parameters appropriate for quantifying the detrital character of marine snow are poorly known. Although the production of marine snow-associated bacteria has been studied previously (Alldredge \& Youngbluth 1985, Alldredge et al. 1986) these authors have not addressed the question of marine snow degradation by attached bacteria. Previous information on the degradation of pelagic particulate organic carbon (POC) by attached bacteria comes from either filter fractionation studies (Kirchman 1983, Simon 1987) or from sediment trap samples (Ducklow et al. 1985, Karl et al. 1988). We studied bacterial production and growth in relation to POC turnover and primary production on marine snow flocs of 4 different types in the waters off California. We also studied bacterial processes in the surrounding seawater to see how the snow environment differs from the surrounding seawater environment with respect to bacterial growth and carbon dynamics. 


\section{MATERIALS AND METHODS}

Samples were collected at 8 stations during a cruise of the RV 'Point Sur' in the Southern California Bight (Stns 1 to 5: Table 1) and the California Current (Stns 6 to 8; Table 1) in September 1987. Abundance of marine snow $>2 \mathrm{~mm}$ was measured visually by a SCUBA diver who swam 3 replicate horizontal transects at depths of 10 to $15 \mathrm{~m}$ while counting marine snow passing through a hoop attached to a General Oceanics flowmeter (Model 2100) equipped with a low speed rotor. Divers also collected marine snow $>2 \mathrm{~mm}$ and surrounding seawater samples.

Eight marine snow samples from each station were examined microscopically and categorized in terms of their morphology or component particle composition: (1) larvacean houses, marine snow consisting of a larvacean house and any other particles attached to it; (2) diatom flocs, marine snow consisting primarily of diatoms $(\mathrm{v} / \mathrm{v})$ and at least $30 \%$ diatoms and diatom frustules; (3) miscellaneous aggregates, marine snow of which $>80 \%$ of its volume was unidentifiable debris; (4) fecal aggregates, if $>50 \%$ of its volume was occupied by fecal pellets. Greater than $95 \%$ of the marine snow at any one station was of a single type and composition (Alldredge \& Gotschalk 1990).

Primary production (PP), dry weight, chlorophyll a (chl $a_{\text {; }}$ corrected for phaeopigments) were measured on 30 individual marine snow flocs and on surrounding seawater at midday, within 90 min of sample collection, as described in Alldredge \& Gotschalk (1990). Briefly, each sample was pipetted into a glass tissue grinder and surrounding seawater was added to bring the volume to $4 \mathrm{ml}$. The marine snow was then gently disrupted by 10 cavitation-free strokes and the resulting particle suspension divided into two $2 \mathrm{ml}$ aliquots. ${ }^{14} \mathrm{C}$-bicarbonate fixation was determined on one aliquot at an irradiance of $150 \mu \mathrm{E} \mathrm{m}^{-2} \mathrm{~s}^{-1}$, which was the light intensity at 7 to $10 \mathrm{~m}$. After incubation the sample was filtered onto a $25 \mathrm{~mm}, 0.4 \mu \mathrm{m}$ Nuclepore filter

Table 1. Marine snow type, sampling location, and abundance of flocs. Misc: miscellaneous aggregates; Larv. larvacean houses

\begin{tabular}{|lccc|}
\hline $\begin{array}{l}\text { Snow type } \\
\text { (Stn no.) }\end{array}$ & Location & $\begin{array}{c}\text { Abundance } \\
\left(1^{-1}\right)\end{array}$ \\
\hline Diatom & $(1)$ & $33^{\circ} 43.25^{\prime} \mathrm{N}, 119^{\circ} 30.68^{\prime} \mathrm{W}$ & $1.05 \pm 0.06$ \\
Diatom & $(7)$ & $34^{\circ} 35.31^{\prime} \mathrm{N}, 121^{\circ} 01.14^{\prime} \mathrm{W}$ & $1.65 \pm 0.10$ \\
Misc. & $(2)$ & $33^{\circ} 12.10^{\prime} \mathrm{N}, 119^{\circ} 21.29^{\prime} \mathrm{W}$ & $0.85 \pm 0.07$ \\
Larv. & $(3)$ & $33^{\circ} 28.96^{\prime} \mathrm{N}, 119^{\circ} 34.23^{\prime} \mathrm{W}$ & $0.50 \pm 0.01$ \\
Larv. & $(4)$ & $33^{\circ} 58.09^{\prime} \mathrm{N}, 120^{\circ} 19.31^{\prime} \mathrm{W}$ & $0.59 \pm 0.09$ \\
Larv. & $(5)$ & $34^{\circ} 18.50^{\prime} \mathrm{N}, 121^{\circ} 11.40^{\prime} \mathrm{W}$ & $0.41 \pm 0.03$ \\
Fecal & $(6)$ & $35^{\circ} 20.06^{\prime} \mathrm{N}, 122^{\circ} 15.53^{\prime} \mathrm{W}$ & $0.52 \pm 0.05$ \\
Fecal & $(8)$ & $34^{\circ} 34.94^{\prime} \mathrm{N}, 121^{\circ} 43.42^{\prime} \mathrm{W}$ & $0.20 \pm 0.02$ \\
\hline
\end{tabular}

which had been pre-weighed on a Cahn Electrobalance (Model 4600). The filter was then dried in a desiccator, re-weighed for determination of particle dry weight and radioassayed to determine ${ }^{14} \mathrm{C}$-fixation. POC was calculated from dry weight measurements by assuming that POC was $15 \%$ of dry weight (Alldredge 1979). Independent checks by Gotschalk \& Alldredge (1989) showed that disruption of marine snow did not significantly reduce photosynthetic activity or cause cell breakage (the latter checked by scanning electron microscopy)

The second $2 \mathrm{ml}$ aliquot of the marine snow suspension (above) was filtered onto a Whatman GF/F glass fiber filter for chl a determination, which was made using standard fluorimetric methods (Parsons et al. 1984). Phytoplankton biomass carbon (PhytoC) was calculated on the basis of chl a concentrations using a C:chl a ratio of 40 which was the mean of Southern California Bight samples analyzed by Eppley et al. (1977). We realize that the $\mathrm{C}$ :chl a ratio can vary considerably (12 to 89; Eppley et al. 1977). Better estimates can be made on the basis of POC and chl a measurements (Eppley et al. 1977). Eppley et al. (1977) determined the $C: c h l$ a ratios for total seawater samples and not specifically for particles. Since we did not take POC samples from the surrounding water we used their mean value of 40 for our calculation.

Bacteria were counted by acridine orange (AO) epifluorescence microscopy (Hobbie et al. 1977). Aggregates were first treated with pyrophosphate followed by ultrasonication to dissociate particle-bound bacteria (Velji \& Albright 1986). Bacterial cell volumes were determined on enlarged AO micrographs with a digitizer according to Simon (1987). Bacterial cell protein $\left(\mathrm{P}\right.$; fg cell $\left.{ }^{-1}\right)$ was calculated from the volume (V; $\mu \mathrm{m}^{3}$ ) by the equation $\mathrm{P}=104.5 \times \mathrm{V}^{0.59}$ (Simon \& Azam 1989). The factor 104.5 replaces 88.6 in Simon \& Azam (1989) to correct for amino acids not detected in their protein measurements $(18 \%)$. Cell $\mathrm{C}$ was calculated from cell protein assuming a $C$ :protein ratio of 0.86 (Simon \& Azam 1989). Bacterial biomass C (BOC) was calculated from cell counts and cell $C$ estimates.

Bacterial protein production (BPP) was determined by using ${ }^{14} \mathrm{C}$-leucine (Leu) incorporation into the protein fraction. Bacterial cell multiplication (BCM) was determined using ${ }^{3} \mathrm{H}$-thymidine ( $\mathrm{TdR}$ ) incorporation into the DNA. Since marine snow flocs may differ in size and composition we measured BPP and BCM simultaneously on the same sample by a double-labelling technique in which both Leu and TdR were added simultaneously (Chin-Leo et al, 1987, Simon et al. 1987, Chin-Leo \& Kirchman 1988). For this purpose 4 to 6 marine snow flocs were pooled in $3 \mathrm{ml}$ of $0.2 \mu \mathrm{m}$ pre-filtered seawater. Triplicates and a control killed with buffered formalin $(\mathrm{pH} 8 ; 0.4 \%$ final concen- 
tration) were incubated with ${ }^{14} \mathrm{C}(\mathrm{U})$-Leu $(300 \mathrm{mCi}$ $\mathrm{mmol}^{-1}$, New England Nuclear) and ${ }^{3} \mathrm{H}-\mathrm{TdR}(70 \mathrm{Ci}$ $\mathrm{mmol}^{-1}$. New England Nuclear) at saturating concentrations of $20 \mathrm{nM}$ each. We found that incorporation rates were maximized at $20 \mathrm{nM}$ additions. Samples were incubated at in situ temperature $\left( \pm 2{ }^{\circ} \mathrm{C}\right)$ in the dark and incubations were stopped with formalin after $1 \mathrm{~h}$. Samples were then placed on ice and an equal volume of ice-cold $10 \%$ trichloracetic acid (TCA) was added to extract the soluble pools. After 30 min the samples were filtered onto $0.45 \mu \mathrm{m}$ Millipore filters, rinsed with particle-free seawater, followed by a rinse with 5\% TCA, and radioassayed. Independent tests showed that $51 \pm 18 \%(\mathrm{~N}=6)$ of Leu in the cold TCA precipitate remained in the hot TCA insoluble fraction (protein) and $80 \pm 20 \%$ of $\mathrm{TdR}$ in the nucleic acid fraction. The percentage of Leu in the hot TCA fraction was unusually low; previous studies found it to be about $90 \%$ (Kirchman et al. 1985, Simon \& Kirchman unpubl.).

Bacterial carbon production (BPP-C) was calculated from Leu incorporation rates ( Leu $_{1 n}$ ) by the relationship: BPP-C $\left(\mathrm{g} \mathrm{C} \mathrm{l}^{-1} \mathrm{~h}^{-1}\right)=\operatorname{Leu}_{\mathrm{inc}} \times \mathrm{F}_{1} \times 0.86 \times 3595$, assuming a 2 -fold isotope dilution (Simon \& Azam 1989). $F_{1}$ is the amount of Leu in the protein fraction as $\%$ of the ice-cold TCA precipitate $(51 \%)$ and 0.86 is the ratio of C:protein in marine bacteria (Simon \& Azam 1989). Bacterial cell multiplication rate (BCM) was calculated from $\mathrm{TdR}$ incorporation rates $\left(\mathrm{TdR}_{\mathrm{Lnc}}\right)$ by the relationship: BCM (cells $\mathrm{l}^{-1} \mathrm{~h}^{-1}$ ) = $\mathrm{TdR}_{\text {inc }} \times \mathrm{F}_{2} \times 1.7 \times 10^{18}$ (Fuhrman \& Azam 1982). $\mathrm{F}_{2}$ is the TdR proportion of the DNA fraction as \% of the icecold TCA precipitate $(80 \%)$.

The measured BPP and BCM values might have been affected by pre-filtration, possibly due to release of dissolved organic matter by cell breakage (Fuhrman \& Bell 1985). As a check we compared the rates of TdR incorporation by marine snow flocs either suspended in pre-filtered seawater or in unfiltered seawater (and corrected for BPP and BCM values due to free-living bacteria). The 2 rates were comparable (data not shown).

Bacterial specific growth rates $(k)$ were calculated on the basis of cell counts and BCM measurements assuming exponential growth.

BPP and BCM in the surrounding seawater were measured by double-labelling $10 \mathrm{ml}$ of seawater with Leu and $\mathrm{TdR}$ at $10 \mathrm{nM}$ final concentration each, as described for marine snow. At $10 \mathrm{nM}$ the label incorporation in the seawater was found to be maximal.

\section{RESULTS AND DISCUSSION}

The abundance and composition of marine snow across our study area was quite variable (Table 1 ). The abundance varied by a factor of 8 with both the lowest $\left(0.2 \mathrm{I}^{-1}\right)$ and the highest $\left(1.65 \mathrm{I}^{-1}\right)$ values occurring in the California Current.

Bacterial abundance on marine snow at different stations varied considerably, between 0.32 and $2.01 \times 10^{6}$ cells per marine snow floc (Table 2 ). Calculated $\mathrm{BOC}$ values were in the range of 18.2 and $134.4 \mathrm{ng} C$ per marine snow floc accounting for 20 to $87 \%$ of PhytoC + BOC (mean $=42 \pm 30 \%$ ), except at Stn 7 where this value was only $3 \%$ (Table 2 ). The low value at Stn 7 may be explained by the fact that marine snow there appeared to be composed of freshly aggregated diatoms and had very high chl $a$ and $\mathrm{PP}$. BOC fractions of PhytoC $+\mathrm{BOC}$ in the surrounding seawater (mean $=55 \pm 19 \%$ ) in general were not significantly different from fractions on marine snow.

BOC and PhytoC accounted for very small fractions of $\mathrm{POC}$ on marine snow, $<1$ to 10 and 2 to $13 \%$, respectively (Table 2 ). This contrasts with values of 20 to $50 \%$ typical of the bulk water of oligo- to mesotrophic pelagic ecosystems (Simon \& Tilzer 1987, Cho \& Azam 1988a, 1990). On the basis of this criterion

Table 2. Bacterial cell numbers, bacterial biomass carbon (BOC), phytoplankton carbon (PhytoC), particulate organic carbon (POC), BOC/(PhytoC $+\mathrm{BOC}), \mathrm{BOC} / \mathrm{POC}$, and PhytoC/POC on marine snow. For comparison $\mathrm{BOC} /(\mathrm{PhytoC}+\mathrm{BOC})$ is also given for the surrounding seawater (SW). nd: not determined. Other abbreviations as in Table 1

\begin{tabular}{|c|c|c|c|c|c|c|c|c|c|}
\hline \multirow{2}{*}{\multicolumn{2}{|c|}{$\begin{array}{l}\text { Snow type } \\
\text { (Stn no.) }\end{array}$}} & \multirow{3}{*}{$\begin{array}{c}\text { Bacteria } \\
\left(10^{6} \text { cells }\right)\end{array}$} & \multirow{3}{*}{$\begin{array}{c}\mathrm{BOC} \\
(\mathrm{ng} \mathrm{C}) \\
17.9\end{array}$} & \multirow{3}{*}{$\begin{array}{c}\begin{array}{c}\text { PhytoC } \\
\text { (ng C) }\end{array} \\
81.4 \pm 23\end{array}$} & \multirow{3}{*}{$\begin{array}{c}\mathrm{POC} \\
\mu \mathrm{gC} \\
3.1 \pm 0.9\end{array}$} & \multirow{3}{*}{$\begin{array}{c}\mathrm{BOC} / \mathrm{POC} \\
0.01\end{array}$} & \multirow{3}{*}{$\begin{array}{c}\text { PhytoC/ } \\
\text { POC } \\
0.03\end{array}$} & \multicolumn{2}{|c|}{$\mathrm{BOC} /($ PhytoC $+\mathrm{BOC})$} \\
\hline & & & & & & & & Snow & SW \\
\hline Diatom & (1) & & & & & & & 0.21 & nd \\
\hline Diatom & (7) & $0.71 \pm 0.09$ & 25.8 & $1172.1 \pm 1116$ & $8.8 \pm 6.5$ & $<0.01$ & 0.13 & 0.03 & 0.21 \\
\hline Misc. & $(2)$ & $1.71 \pm 0.14$ & 110.5 & $64.3 \pm 64$ & $2.0 \pm 1.9$ & 0.07 & 0.03 & 0.67 & 0.58 \\
\hline Larv. & (3) & $0.90 \pm 0.11$ & 88.9 & $68.9 \pm 112$ & $1.6 \pm 1.9$ & 0.06 & 0.04 & 0.61 & 0.67 \\
\hline Larv. & (4) & $0.42 \pm 0.06$ & 28.5 & $85.4 \pm 47$ & $1.7 \pm 0.9$ & 0.03 & 0.07 & 0.29 & 0.47 \\
\hline Larv. & (5) & $0.79 \pm 0.10$ & 134.4 & $24.1 \pm 20$ & $1.7 \pm 0.3$ & 0.10 & 0.02 & 0.87 & 0.61 \\
\hline Fecal & (6) & $0.58 \pm 0.08$ & 53.8 & nd & nd & nd & nd & nd & nd \\
\hline Fecal & $(8)$ & $0.06 \pm 0.01$ & 18.2 & $55.3 \pm 115$ & $1.5 \pm 1.1$ & 0.03 & 0.03 & 0.27 & 0.77 \\
\hline
\end{tabular}


Table 3. Bacterial cell multiplication rate (BCM), bacterial specific growth rate ( $\mathrm{k}$ ), bacterial carbon production (BPP-C), POC/ BPP-C, cell carbon, and BPP-C/PP of marine snow-associated and free-living bacteria in the surrounding water. POC/BPP-C is calculated as the net ratio and also considering a bacterial carbon assimilation efficiency of $30 \%$ (gross). The cell carbon was calculated (a) by the ratio of BPP-C to BCM $\left(C_{n}\right)$, and (b) from cell volume measurements $\left(C_{d y}\right)$. Abbreviations as in Tables 1 and 2

\begin{tabular}{|c|c|c|c|c|c|c|c|c|c|c|}
\hline \multirow{2}{*}{\multicolumn{2}{|c|}{$\begin{array}{l}\text { Snow type } \\
\text { (Stn no.) }\end{array}$}} & \multirow[t]{2}{*}{$\begin{array}{c}\mathrm{BCM} \\
\left(10^{5} \text { cells d } \mathrm{d}^{-1}\right)\end{array}$} & \multirow[t]{2}{*}{$\frac{k}{\left(d^{-1}\right)}$} & \multirow[t]{2}{*}{$\begin{array}{c}\text { BPP-C } \\
\left(n g C d^{-1}\right)\end{array}$} & \multicolumn{2}{|c|}{$\begin{array}{c}\mathrm{POC} / \mathrm{BPP}-\mathrm{C} \\
\text { (d) }\end{array}$} & \multicolumn{2}{|c|}{$\begin{array}{c}\text { Cell carbon } \\
\text { (fg C) }\end{array}$} & \multirow[t]{2}{*}{$\mathrm{C}_{n} / \mathrm{C}_{\mathrm{av}}$} & \multirow[t]{2}{*}{$\mathrm{BPP} \cdot \mathrm{C} / \mathrm{PF}$} \\
\hline & & & & & Net & Gross & $\mathrm{C}_{\mathrm{n}}$ & $C_{d v}$ & & \\
\hline \multicolumn{11}{|c|}{ Marine snow } \\
\hline Diatom & (1) & $2.6 \pm 0.69$ & 0.67 & $27.2 \pm 5.07$ & 115 & 35 & 103 & 46 & 2.2 & 0.10 \\
\hline Diatom & (7) & $4.2 \pm 0.46$ & 0.96 & $25.2 \pm 6.30$ & 349 & 105 & 60 & 60 & 1.0 & 0.02 \\
\hline Misc. & (2) & $2.9 \pm 0.51$ & 0.15 & $29.9 \pm 10.2$ & 67 & 20 & 101 & 55 & 1.8 & 0.69 \\
\hline Larv. & (3) & $1.2 \pm 0.22$ & 0.06 & $6.2 \pm 0.68$ & 258 & 77 & 52 & 49 & 1.1 & 0.08 \\
\hline Larv. & (4) & $0.7 \pm 1.12$ & 0.09 & $12.7 \pm 5.08$ & 107 & 32 & 194 & 40 & 4.9 & 0.19 \\
\hline Larv. & (5) & $1.5 \pm 0.02$ & 0.08 & $8.0 \pm 0.50$ & 212 & 71 & 54 & 70 & 0.8 & 0.29 \\
\hline Fecal & (6) & $1.0 \pm 0.21$ & 0.08 & $4.4 \pm 0.58$ & nd & nd & 46 & 48 & 1.0 & nd \\
\hline Fecal & (8) & $0.5 \pm 0.10$ & 0.13 & $3.0 \pm 0.50$ & 333 & 100 & 73 & 57 & 1.3 & 0.08 \\
\hline \multicolumn{11}{|c|}{ Surrounding seawater } \\
\hline Diatom & (1) & $310 \pm 43^{\mathrm{a}}$ & 0.03 & $809 \pm 170^{\circ}$ & nd & nd & 26 & 23 & 1.1 & 0.03 \\
\hline Diatom & (7) & $737 \pm 228$ & 0.14 & $2404 \pm 240$ & nd & nd & 33 & 31 & 1.1 & 0.05 \\
\hline Misc. & (2) & nd & nd & $930 \pm 316$ & nd & nd & nd & 17 & nd & 0.08 \\
\hline Larv. & (3) & $490 \pm 98$ & 0.06 & $581 \pm 139$ & nd & nd & 12 & 20 & 0.6 & 0.06 \\
\hline Larv. & (4) & $298 \pm 57$ & 0.04 & $764 \pm 168$ & nd & nd & 25 & 20 & 1.3 & 0.02 \\
\hline Larv. & (5) & $907 \pm 36$ & 0.16 & $278 \pm 75$ & nd & nd & 3 & 19 & 0.2 & 0.02 \\
\hline Fecal & (6) & $215 \pm 47$ & 0.03 & $763 \pm 137$ & nd & nd & 36 & 26 & 1.4 & nd \\
\hline Fecal & (8) & $511 \pm 41$ & 0.06 & $382=34$ & nd & nd & 7 & 22 & 0.3 & 0.03 \\
\hline \multicolumn{11}{|c|}{${ }^{a}$ Rate is $1^{-1} \mathrm{~d}^{-1}$} \\
\hline
\end{tabular}

marine snow appeared to be a detritus-dominated system.

Total variation of bacterial carbon production (BPPC) for all stations was from 3 to $28 \mathrm{ng} \mathrm{C} \mathrm{d^{-1 }}$ per marine snow floc (Table 3). Since the size of marine snow flocs was quite variable we have normalized BPP-C to their POC content. Note that BPP-C/POC has the dimensions of $\mathrm{d}^{-1}$. We have chosen to express the normalized rates as the inverse of the this ratio. The values are all within a factor of 5 ( 67 to $349 \mathrm{~d}_{\text {i }}$ mean $=206 \pm 113 \mathrm{~d}$ ) without showing any station-specific pattern. It would be interesting to determine whether this narrow range of normalized BPP-C values represents a range for marine snow in oligo- to mesotrophic waters in general.

We have also calculated the turnover time of marine snow POC due to bacterial consumption, as POC/(BPP$\mathrm{C} \times 0.33$ ), by assuming a $30 \%$ carbon assimilation efficiency for bacteria on marine snow (Table 3). The turnover times range from 20 to $105 \mathrm{~d}$. Comparable turnover times for POC in the euphotic zone due to attached bacteria have been calculated in other studies (40 to $50 \mathrm{~d}$; Kirchman 1983, Simon 1987). Based on sediment trap deployments in the mesopelagic zone, Ducklow et al. (1985) calculated turnover times of trapcollected POC due to decomposition by attached bacteria to be much longer ( 90 to $>700 \mathrm{~d}$ ). Cho \& Azam (1988a) also found that the carbon demand of particleassociated bacteria accounted for a minor fraction of the depth dissipation of $\mathrm{POC}$; most of the depth dissipation of POC could be ascribed to the carbon demand of free-living bacteria. They proposed a large scale solubilization of POC in the mesopelagic zone. On the other hand, abandoned larvacean houses and fresh salp feces are turned over within a few days (Pomeroy et al. 1984, Davoll \& Silver 1986). Our marine snow POC turnover times solely due to the carbon demand of attached bacteria are comparable to the $\mathrm{POC}$ residence times in the euphotic zone in the Southern California Bight (Eppley et al. 1983).

For our calculation of bacterial carbon demand we assumed a carbon assimilation efficiency of $30 \%$. This is considerably lower than the commonly used value of $50 \%$ for seawater samples. However, growth efficiencies of 20 to $30 \%$ have been determined for mixed cultures derived from bacterioplankton assemblages (Bjornsen 1986, Tranvik 1988). These lower growth efficiencies may be more appropriate for the slowgrowing natural bacterial assemblages than maximum growth efficiencies of 50 to $60 \%$ found for fast-growing cultures (Calow 1977).

Specific growth rates $(k)$ of bacteria on marine snow exhibited great variations, ranging from 0.06 to $0.96 \mathrm{~d}^{-1}$ (Table 3). The highest values $\left(0.67\right.$ and $\left.0.96 \mathrm{~d}^{-1}\right)$ were observed at the 2 stations with diatom flocs. All other values were $<0.15 \mathrm{~d}^{-1}$. These growth rates are in the range of growth rates of attached bacteria in other 

bacterial production (BPP-C) on marine snow (upper panel) and in the surrounding water (lower panel). Note the different scales on the upper and lower panel. Primary production was not measured at $\operatorname{Stn} 6$. Vertical bars indicate standard error (SE). Numbers above the panels indicate $\mathrm{PP} \pm \mathrm{SE}$ exceeding the scale. D: diatom flocs; $\mathrm{M}$ : miscellaneous aggregates; L: larvacean houses; F: fecal aggregates
Fig. 1. Primary production (PP) and BPP-based
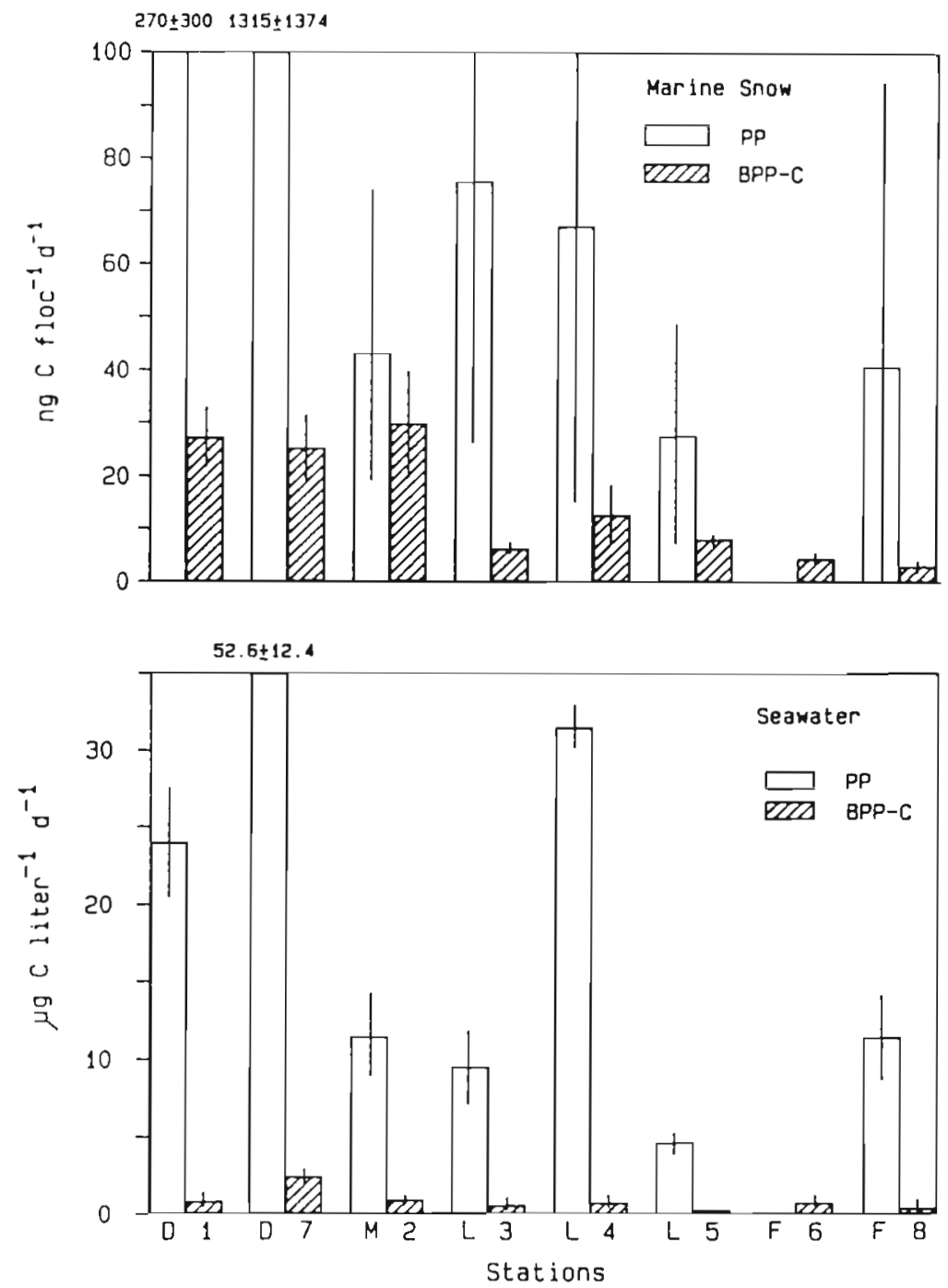

studies (Ducklow \& Kirchman 1983, Alldredge \& Youngbluth 1985, Simon 1988). It is noteworthy that these growth rates are also comparable to growth rates of free-living bacteria in oligo- to mesotrophic waters (Fuhrman \& Azam 1980, 1982, Cho \& Azam 1988a). If we were to define a marine snow environment in terms of the growth rate of bacteria in it, then our diatom flocs would be comparable to the mesotrophic bulk phase waters. All our other marine snow samples would be comparable to oligotrophic bulk phase waters. By this comparison we do not imply any specific similarity of nutrient conditions between marine snow and the bulk phase; our purpose is simply to provide a frame-work for considering the bacterial growth rates on marine snow.

Growth rates of free-living bacteria in the surrounding seawater were slow (0.03 to $0.14 \mathrm{~d}^{-1}$; Table 3$)$. These rates were characteristic for oligotrophic offshore waters (Cho \& Azam 1988a, Fuhrman et al. 1989) even though the chl $a\left(0.2\right.$ to $1.4 \mu \mathrm{g} \mathrm{l}^{-1}$ ) and PP (Fig. 1) values at our stations were quite high. Previous measurements of mesotrophic samples in the Southern California Bight have typically yielded specific growth rates on the order of 0.2 to $2 \mathrm{~d}^{-1}$ (Fuhrman \& Azam 1982). The unexpectedly low growth rates we found might reflect a temporal uncoupling between primary production and bacterial production.

Primary production on marine snow ranged widely, from 8.1 to $2170 \mathrm{ng} \mathrm{C}^{-1} \mathrm{~d}^{-1}$ (Fig, 1). Highest rates of primary production, as for bacterial production, occurred on diatom flocs (Stns 1 and 7). Ratios of BPP-C/PP on marine snow varied between 0.02 and 0.69 across our study area. The mean ratio for all stations was $0.21 \pm 0.23$ which is very close to the ratio 0.20 based on a general relationship between PP and bacterial carbon production for a large variety of aquatic environments (Cole et al. 1988).

The BPP-C/PP ratios in our seawater samples were surprisingly low $(0.02$ to 0.08$)$. This is because of the unexpectedly low bacterial production despite the high 
primary production as discussed. This ratio is much lower than expected from the Cole et al. (1988) relationship and, as mentioned, may reflect an uncoupling between primary production and bacterial production. A similar uncoupling has been reported in cold, oligotrophic environments (Bell \& Kuparinen 1984, Pomeroy $\&$ Deibel 1986). Also, the BPP-C/PP for the surrounding water was much lower than for marine snow. It would be interesting to find out whether this difference is a general phenomenon or whether it is due to the unusually low ratios for the surrounding water in our study.

We measured bacterial carbon production in seawater and on aggregates by the BPP method and cell multiplication by the TdR method. Since the TdR method yields cell production, conversion into bacterial carbon production requires a knowledge of the carbon content of the growing bacteria. An important advantage of the BPP method is that bacterial carbon production can be calculated directly from the protein production data, without the need to know the carbon content of the growing part of the assemblage. The simultaneous use of the TdR method (to measure cell production) and the BPP method (to measure carbon production) in fact allows one to calculate the average carbon content of the new cell $\left(C_{n}\right.$ i Simon \& Azam 1989). In our data set $\mathrm{C}_{n}$ varied widely, from 3.1 to $193.1 \mathrm{fg} \mathrm{C} \mathrm{cell}^{-1}$ (Table 3 ). Interestingly, the $\mathrm{C}_{\mathrm{n}}$ was generally within a factor of 2 (in $73 \%$ of the cases within a factor of 1.5 ) of the average cellular carbon content $\left(C_{a v}\right)$ of the assemblage as determined from cell size measurements. This does not mean, however, that bacterial growth was due to the average-size bacteria for the attached and freeliving assemblages. Even a $\mathrm{C}_{n} / \mathrm{C}_{a v}$ of 1 does not necessarily mean that the carbon content of the new cell equals $C_{a v}$, but that the average carbon content of the new cell equals $C_{a v}$ (unless all cells in the assemblage had the same carbon content).

The $\mathrm{C}_{\mathrm{n}} / \mathrm{C}_{\mathrm{d} v}$ ratio is relevant to the $\mathrm{TdR}$ method for calculating bacterial carbon production (TdR-C) where one assumes that $\mathrm{C}_{n} / \mathrm{C}_{\mathrm{av}}=1$; departure from unity will be a measure of error in determining $\mathrm{TdR}-\mathrm{C}$ on account of this assumption. Other sources of error in the TdR and BPP method may cause errors in the $C_{n}$ measurement itself; so it would not be strictly valid to use $\mathrm{C}_{\mathrm{n}} / \mathrm{C}_{\mathrm{av}}$ to compare the $\mathrm{TdR}$ and BPP methods. Most errors of the 2 methods arise from the need to use conversion factors to calculate cell production or protein synthesis rates. Factors converting Leu incorporation into rates of protein synthesis determined for various aquatic ecosystems and bacterial generation times of 0.5 to 14 d vary only 2 -fold (Simon \& Kirchman 1988 , Simon \& Azam 1989, Simon unpubl.). TdR-conversion factors vary much more (Cho \& Azam 1988b) although in Californian coastal waters total variations is $<2$-fold (Fuhrman \& Azam 1982). Despite a 62-fold variation in
$\mathrm{C}_{\mathrm{n}}$ in our data, $\mathrm{C}_{\mathrm{n}} / \mathrm{C}_{\mathrm{av}}$ varied generally $<2$-fold. If we could generalize from our limited number of measurements here, then the error in historical TdR-C measurements due to the assumption $C_{n} / C_{a v}=1$ would have been $<2$-fold

In conclusion, our results show that bacterial and algal biomass were only minor components of marine snow as compared to POC; thus marine snow appeared to be a detritus-dominated system. It is interesting that even though marine snow is a microenvironment rich in organic matter, marine snow-associated bacteria in general did not grow much faster than the bacteria in the surrounding water, except when they grew on diatom flocs. However, because of the high bacterial abundance on marine snow the turnover time of marine snow POC due to carbon consumption by attached bacteria was rapid enough that bacteria could play a significant role in marine snow degradation.

Acknowledgements. This work was supported by an NSF grant to A.L.A. and NSF and DOE grants to F.A. M.S. was supported by a fellowship from Deutsche Forschungsgemeinschaft. We thank C. Gotschalk, K. Crooker, J. Altstatt, D. Steinberg, B. Harrison, E. Schnitzler for diving and laboratory assistance and the captain and crew of the RV 'Point Sur' for assistance in the field. We also thank D. L. Kirchman, J. A. Fuhrman and 2 anonymous referees for comments on earlier versions of this manuscript.

\section{LITERATURE CITED}

Alldredge, A. L. (1979). The chemical composition of macroscopic aggregates in two neritic seas. Limnol. Oceanogr. 24: 855-866

Alldredge, A. L., Cole, J. J., Caron, D. A. (1986). Production of heterotrophic bacteria inhabiting macroscopic organic aggregates (marine snow) from surface waters. Limnol. Oceanogr. 31: 68-78

Alldredge, A. L., Gotschalk, C. C. (1990). The relative contribution of marine snow of different origins to biological processes in coastal waters. Contin. Shelf Res. 10: 41-58

Alldredge, A. L., Silver, M. W. (1988). Characteristics, dynamics and significance of marine snow. Prog. Oceanogr. 20: 41-82

Alldredge, A. L., Youngbluth, M. J. (1985). The significance of macroscopic aggregates (marine snow) as sites for heterotrophic bacterial production in the mesopelagic zone of the subtropical Atlantic. Deep-Sea Res. 32: 1445-1456

Bell, R. T., Kuparinen, J. (1984). Assessing phytoplankton and bacterioplankton production during the early spring in Lake Erken, Sweden. Appl. environ. Microbiol. 48: 1221-1230

Bjørnsen, P. K. (1986). Bacterioplank ton growth yield in continuous seawater cultures. Mar Ecol. Prog. Ser. 30: 191-196

Calow, P. (1977). Conversion efficiencies in heterotrophic organisms. Biol. Rev. 52: 385-409

Chin-Leo, G., Biggs, R., Kirchman, D. L. (1987). Changes in relative rates of protein and DNA synthesis in natural assemblages of bacteria in response to fluctuating DOM concentrations. EOS Trans. Am. Geophys. Un. 68: 1729

Chin-Leo, G. Kirchman, D. L. (1988). Estimating bacterial production in marine waters from the simultaneous in- 
corporation of thymidine and leucine. Appl. environ Microbiol. 54: 1934-1939

Cho, B. C., Azam, F (1988a). Major role of bacteria in biogeochemical fluxes in the ocean's interior. Nature, Lond. 332: 441-443

Cho, B. C., Azam, F. (1988b). Heterotrophic bacterioplankton production measurement by the tritiated thymidine incorporation method. Ergebn. Limnol. 31: 153-162

Cho, B. C., Azam, F. (1990). Biogeochemical significance of bacterial biomass in the ocean's euphotic zone. Mar Ecol. Prog. Ser. 63: 253-259

Cole, J. J., Findlay, S., Pace, M. L. (1988). Bacterioplankton production in fresh and saltwater ecosystems: a crosssystem overview. Mar. Ecol. Prog. Ser. 43: 1-10

Davoll, P. J., Silver, M. V. (1986). Marine snow aggregates: life history sequence and microbial community of abandoned larvacean houses from Monterey Bay, California. Mar. Ecol. Prog. Ser. 33: 111-120

Ducklow, H. W., Hill, S. M., Gardner, W. D. (1985). Bacterial growth and the decomposition of particulate organic carbon collected in sediment traps. Contin. Shelf Res. 4: 445-464

Ducklow, H. W., Kirchman, D. L. (1983). Bacterial dynamics and distribution during a spring diatom bloom in the Hudson River plume, USA. J. Plankton Res. 5: 333-355

Eppley, R. W., Harrison, W. G., Chisholm, S. W., Stewart, E. (1977). Particulate organic matter in surface waters off Southern Clifornia and its relationship to phytoplankton. J. mar. Res. 35: 67 1-696

Eppley, R. W., Renger, E. H., Betzer, P. R. (1983). The residence time of particulate organic carbon in the surface layer of the ocean. Deep Sea Res. 30: 311-323

Fuhrman, J. A., Azam, F. (1980). Bacterioplankton secondary production estimates for coastal waters of British Columbia, Antarctica, and California. Appl. environ. Microbiol. 39: 1085-1095

Fuhrman, J. A., Azam, F. (1982). Thymidine incorporation as a measure of heterotrophic bacterioplankton production in marine surface waters: evaluation and field results. Mar Biol. 66: 109-120

Fuhrman, J. A., Bell, T M. (1985). Biological considerations in the measurements of dissolved free amino acids in seawater and implications for chemical and microbiological studies. Mar. Ecol. Prog. Ser. 25: 13-21

Fuhrman, J. A., Sleeter, T D., Carlson, C. A., Proctor, L. M (1989). Dominance of bacterial biomass in the Sargasso Sea and its ecological implications. Mar. Ecol. Prog. Ser $57 \cdot 207-217$

Gotschalk, C. C., Alldredge, A. L. (1989). Enhanced primary production and nutrient regeneration within aggregated marine diatoms. Mar Biol. 103: 119-129

This article was submitted to the editor
Hobbie, J. E., Daley, R. J., Jasper, S. (1977). Use of nuclepore filters for counting bacteria by fluorescence microscopy. App. environ. Microbiol. 33: 1225-1228

Kirchman, D. L. (1983). The production of bacteria attached to particles suspended in a freshwater pond. Limnol. Oceanogr 28: 858-872

Kirchman, D. L., K'Nees, E., Hodson, R. E. (1985). Leucine incorporation and its potential as a measure of protein synthesis by bacteria in natural aquatic systems. Appl. environ. Microbiol. 49: 599-607

Karl, D. M., Knauer, G. A., Martin, J. H. (1988). Downward flux of particulate organic matter in the ocean: a particle decomposition paradox. Nature, Lond. 332: 438-441

Parsons, T. R., Maita, Y., Lalli, C. M. (1984). A manual of chemical and biological methods for seawater analysis. Pergamon Press, New York

Pomeroy, L. R., Deibel, D. (1986). Temperature regulation of bacterial activity during the spring bloom in Newfoundland coastal waters. Science 233: 359-361

Pomeroy, L. R., Hanson, R. B., McGillivary, P. A., Sherr, B. F., Kirchman, D. L., Deibel, D. (1984). Microbiology and chemistry of fecal products of pelagic tunicates: rates and fates. Bull. mar. Science 35: 426-439

Simon, M. (1987). Biomass and production of small and large free-living and attached bacteria in Lake Constance. Limnol. Oceanogr. 32: 591-607

Simon, M. (1988). Growth characteristics of small and large free-living and attached bacteria in Lake Constance. Microb. Ecol. 15: 151-163

Simon, M., Alldredge, A. L., Azam, F. (1987). Marine snow: a microenvironment of high bacterial protein production. EOS Trans. Am. geophys. Un. 68: 1697

Simon, M., Azam, F. (1989). Protein content and protein synthesis rates of planktonic marine bacteria. Mar. Ecol. Prog. Ser. 51. 201-213

Simon, M., Kirchman, D. L. (1988). Isotope dilution during bacterial amino acid uptake in the subarctic Pacific: evidence for ammonium utilization by bacteria. EOS Trans. Am. geophys. Un. 69: 1146

Simon, M., Tilzer, M. M. (1987). Bacterial response to seasonal changes in primary production and phytoplankton biomass in Lake Constance. J. Plankton Res. 9: 535-552

Tranvik, L. (1988). Availability of dissolved organic carbon for planktonic bacteria in oligotrophic lakes of different humic content. Microb. Ecol. 16: 311-322

Velji, M. J., Albright, L. T (1986). Microscopic enumeration of attached marine bacteria of seawater, marine sediment, fecal matter, and kelp blade samples following pyrophosphate and ultrasound treatment. Can. J. Microbiol. 32: $121-126$

Manuscript first received: December 22, 1989

Revised version accepted: May 28, 1990 